\title{
On the Improvement of College English Teachers' Quality from the Perspective of Ideological and Political Education
}

\author{
Zhao $\mathrm{Li}^{1}$ \\ ${ }^{1}$ School of Foreign Languages, Dalian Jiaotong University, DaLian, Liaoning, China \\ 3521051@qq.com

\begin{abstract}
College English course shoulders the major responsibility of ideological and political education. College English teachers should improve their ideological quality, political awareness, moral characteristics and humanistic quality. They should explore effective ways to integrate the ideological and political content into language teaching, so as to ensure the implementation of ideological and political construction in the course.
\end{abstract}

Keywords: ideological and political education, ideological quality and political awareness, English teachers

\section{课程思政背景下大学英语教师思政素养提高途径探究}

\author{
赵骊 ${ }^{1}$
}

${ }^{1}$ 大连交通大学外语学院, 大连, 辽宁, 中国

3521051@qq.com

\section{摘要}

大学英语作为高校的主干通识课程之一，担负着 “课程思政” 的重要职责。全面推进课程思政建设，教师是关 键。广大英语教师要强化育人意识, 提升自身思政素养, 找准育人角度, 积极探索将思政内容融入语言教学的 有效途径, 提升育人能力, 采用灵活多样的教学方法, 落实好立德树人根本任务, 确保课程思政建设落地落实、 见功见效。

关键词: 课程思政，思政素养，英语教师

\section{1.前言}

“课程思政”是指以构建全员、全程、全课程育人 格局的形式将各类课程与思想政治理论课同向同行, 形成协同效应，把“立德树人”作为教育的根本任务的 一种综合教育理念。党的十八大会议以来, 习近平总 书记在一系列重要讲话中多次提及思政教育的重要 性。2016 年的全国高校思想政治工作会议上, 习总 书记指出: “做好高校思想政治工作, 要用好课堂教 学这个主渠道, 思想政治理论课要坚持在改进中加强, 提升思想政治教育亲和力和针对性, 满足学生成长发 展需求和期待, 其他各门课都要守好一段渠、种好责 任田, 使各类课程与思想政治理论课同向同行, 形成
协同效应[1]。”2020 年 6 月，教育部发布《高等学校 课程思政建设指导纲要》, 强调“深入挖掘各类课程和 教学方式中蕴含的思想政治教育资源, 让学生通过学 习, 掌握事物发展规律, 通晓天下道理, 丰富学识, 增长见识, 塑造品格, 努力成为德智体美劳全面发展 的社会主义建设者和接班人。高校课程思政要融入课 堂教学建设, 作为课程设置、教学大纲核准和教案评 价的重要内容, 落实到课程目标设计、教学大纲修订、 教材编审选用、教案课件编写各方面，贯穿于课堂授 课、教学研讨、实验实训、作业论文各环节[2]。”

\section{2. 推进大学英语“课程思政”的必要性}

要做好高校思想政治工作，不但要把握思想政治 
理论课的核心地位, 还需要包括大学英语在内的所有 课程积极发挥协同作用，形成合力，真正做到全课程 育人。《大学英语教学指南》(2020 版) 明确提出: 大学英语教学应主动融入学校课程思政教学体系, 使 之在高等学校落实立德树人根本任务中发挥重要作 用。课程设置应该以立德树人为根本任务, 以提高课 程质量为抓手, 对标一流课程建设的要求, 体现高阶 性、创新性和挑战度, 将课程思政理念和内容有机融 入课程。

\section{1. 大学英语作为通识课, 为思政教育提供有 利平台}

大学英语课程是几乎所有非英语专业本科生必 修的通识教育类课程。培养“全人”是通识教育的主要 目的, 而一个全面发展的人首先应具备良好的道德品 质, 所以大学英语课承载着立德树人的使命, 为高校 思政教育提供有利平台。大学英语课的授课对象是刚 刚步入大学校园的青年学子, 他们正处在人生观, 价 值观和世界观形成的重要时期, 大学英语教师有责任 和义务帮助学生迈出这人生成长的关键一步。教师在 课堂授课中, 应引导学生辩证地看待教材中西方的意 识形态和价值观, 明辨是非, 抵制不良社会思潮的侵 蚀, 通过文化对比等方式, 传播中华民族优秀传统文 化，增强学生的文化自信和爱国情怀。

大学英语课时量多, 学生一般需要学习一年至两 年的大学英语课, 教师与学上接触时间长且互动频繁, 教师言传身教的影响广泛而深远。因此, 大学英语课 为思政教育提供了一个十分有利的平台。

\section{2. 大学英语兼具工具性和人文性, 为向世界 传播中国声音奠定良好基础}

语言是文化的重要组成部分, 是传播思想文化的 有效媒介, 兼具工具性和人文性双重属性。大学英语 作为语言类通识课程, 讲授英语语言知识, 训练语言 应用技能、培养学生学习策略和跨文化交际能力。更 为重要的是, 要发挥大学英语人文学科的优势, 因势 利导, 培养学生的批判思维, 理性看待中西方文化的 碰撞。在日常教学中融入中华民族优秀传统文化、社 会主义核心价值观等思想政治内容, 让学生用英语这 一工具, 讲好中国故事, 传播中国文化, 让世界听到 中国的声音。

长期以来, 由于一些西方媒体别有用心的不实宣 传, 和语言不通造成的民间交流的壁垒, 使得西方国 家普通民众对中国政府和人民形成一些误解。青年学 子担负着向世界介绍中国, 向世界弘扬中华优秀传统 文化的责任和使命。大学英语“课程思政”既为青年学 子奠定了语言技能基础, 同时又培养了他们的民族文 化自信, 为他们向世界传播中国的声音保驾护航。

\section{3. 高校英语教师在课程思政中面临的困境}

\section{1. 知识结构欠缺}

高校英语教师绝大多数来源于各大院校英语专 业毕业生。由于英语专业课程基本围绕英语语言技能, 英美国家历史文化等方面开设, 所以英语教师在求学 期间把大部分的时间和精力都花在了语言知识的摄 取和各种语言技能的练习上, 文化学习的重心也偏向 于英美国家文化、历史和风土人情等，而对中国优秀 的传统文化和经典文学很少涉猎。自身知识结构的欠 缺, 导致英语教师在走上讲台后, 将教学重点放在英 语语言的工具性上, 忽略了其人文性。在实际教学中, 会偏向于英语文化教育而忽视了中国文化。很多英语教师由 于自身文化素养的限制, 备课中对中国传统文化知识 常常捉襟见肘, 无法将中华文明、中国文化融入到课 堂教学中。传统中国文化在外语教学中的缺失, 容易造成学 生缺乏民族文化自信心，在跨文化交流时，出现本土文化“失语” 现象。

\section{2. 思政意识不足}

有一部分高校英语老师对“课程思政”认识存在 误区, 认为思想政治教育是思政课程老师的任务, 与 自己无关或者关系不大。在英语课上进行思政教育会 占用语言专业知识的学习时间, 导致教学计划无法完 成。有些老师认为语言知识和思政内容很难建立联系, 无法融合, 从心底里抵触在外语课堂上开展思政教育。 因此在教学设计中, 要么完全忽略思政元素, 要么就 是机械生硬地堆砌思政素材。这种牵强突元的教学方 式, 无法激发学生的学习兴趣, 因此也无法达到良好 的育人目的。

另外也有一部分英语老师，非常认同“课程思政” 的理念, 但是由于自身没有接受过系统的思政专业学 习, 缺乏思政教育思维, 因此很难捕捉到英语教学和 思政教育之间的关联点，无法恰到好处的将思政教育 融入到外语教学中。课堂设计中的思政素材和语言教 学材料相关性不高, 思政教育无法做到以润物无细无 声的自然方式影响学生; 或者教师对思政素材挖掘深 度不够, 无法使学生的认知得到升华。

\section{3. 教材设计局限}

教材是课堂授课依托的主要载体。无论是教师设 计教学内容, 还是学生获取语言素材, 都离不开教材。 目前已出版的大学英语教材, 素材多节选自英美报章 或文学作品, 侧重于介绍英美国家的历史文化和风土 人情, 较少涉及中国文化元素, 更遑论社会主义核心 价值观。中国文化输入不足会带来一些负面影响。从 大学英语的工具性角度来看, 学生在接收到的语言输 入中很少有关于本民族文化的词汇和语句, 导致学生 在语言输出时找不到与中国文化元素或社会主义核 心价值观对应的恰当表达方式，“无话可说”。从人文 
性角度来看, 清一色的西方文化和价值观的灌输, 缺 少关于我国历史、政治、哲学等方面的知识的对比学 习, 不利于学生批判思维的培养, 学生容易照搬照抄、 盲目崇拜，从而削弱民族自豪感和文化自信心。

\section{4. 教学手段单一}

信息技术大爆炸时代孕育出的互联网，移动客户 端, 电子书籍等丰富了人们获取知识的途径, 同时也 给传统的课堂教学带来了挑战。很多大学英语教师虽 然有多年积累的丰富的教学经验, 但是缺少技术培训, 没有找到能够将这些传统的教学方法跟现代技术相 融合的途径。还有一些学校硬件设备更新滞后, 无法 支撑起基于互联网技术的互动课堂。这些原因导致很 多大学英语课堂还在沿用以教师为中心的传统授课 模式。当代大学生是伴随信息化技术发展成长起来的 一代, 他们更适应多媒体交互式的学习方法。传统单 一的教学手段无法调动起学生的学习兴趣, 学生参与 感低, 思政教学内容容易变成呆板的说教, 学生左耳 听右耳出, 无法达到育人效果。

\section{4. 高校英语教师思政素养提高途径}

\section{1. 加强自身道德修养}

习近平在 2016 年全国高校思想政治工作会议 强调, 教师是人类灵魂的工程师, 承担着神圣使命。 传道者自己首先要明道、信道。高校教师要坚持教育 者先受教育, 努力成为先进思想文化的传播者、党执 政的坚定支持者, 更好担起学生健康成长指导者和引 路人的责任。

首先, 高校英语教师要以德立身、以德立学、以 德施教。加强自身道德修养, 无论在为人行事还是在 工作科研中, 都要做到正直诚信, 公平公正。育人先 正己, 要加强师德师风建设, 坚持教书和育人相统一, 坚持言传和身教相统一, 只有这样才能用自己的人格 魅力引领学生形成正确的世界观、人生观和价值观。

其次, 高校英语教师要多关心时事, 了解国家 发展的大政方针和指导思想。不能“两耳不闻窗外事, 一心只读圣贤书”, 要把坚持潜心问道和关注社会相 统一。大学英语老师应该加强政治理论学习, 关注党 和国家领导人在一些重要会议上的讲话, 领会会议精 神, 做到与时俱进。大学英语老师要站稳政治立场, 把握政治方向, 坚定共产主义信仰和中国特色社会主 义信念, 要善于从政治角度看问题, 将社会主义核 心价值观、家国情怀等融入到英语课程教学中。

\section{2. 提高中国传统文化素养}

悠悠华夏，千载文明。优秀的传统文化是中华民 族的精神脊梁, 是民族生命得以延续的根基。丢弃了 优秀的传统文化, 等于丢弃了民族的根和魂。大学英 语教师一定要注重自身中国文化素养的提升。英语老
师要经常阅读历史典籍、经典文学作品等, 也可以听 一些关于中国传统文化的知识讲座, 或者观看一些介 绍中国历史、地理、不同地域风土人情等的纪录片。 通过多种方法, 使自己保持一种学习的状态, 不断吸 纳更丰富的关于中国优秀传统文化的知识, 以弥补自 身人文知识的欠缺。

大学英语教师只有通过不断学习, 提升自身的传 统文化素养, 才能了解中国历史以及中国在国际社会 的影响地位。一个具有家国情怀的教师才能使思政 教育内容具有感染力, 才能给学生以美的启迪, 才能 培养学生树立文化自信心, 才能将中国优秀传统文化 向世界传播。

\section{3. 充分挖掘教材思政元素}

教材作为大学英语教学的重要载体, 是思政素材 的主要来源, 广大教师需要孜孜不倦地做好深入细 致的挖掘和研究工作。大学英语教材虽然在选材上倾 向欧美英语国家的素材, 但教材内容在入选时就被考 虑了一定的思想性, 且涵盖广泛的人文元素。素材背 后所蕴含的一些富含正能量的价值观是不同语言不 同民族所共同推崇的文化瑰宝。因此，英语教师对课 文的理解切不可停留在表面, 必须深入细致的研究和 挖掘教材中隐含的思政元素, 查阅相关资料, 以便在 讲授语言知识的过程中恰到好处地引入育人内容, 如 盐入水, 润物无声地将思政元素播种在学生心中, 潜 移默化地提升学生的思想政治素养。同时教师对中 国传统文化也要了然于心, 挖掘课本中蕴含的中西方 文化的差异, 通过文化对比, 培养学生的批判思维, 明辨良菱。文化对比也有助于培养学生的跨文化交际 能力, 让学生运用英语表达介绍中国文化。教学设计 不能生搬硬套, 教师要对教材进行充分的理解和内化 之后, 隐性地将思政教育融入到课堂教学和课内外 师生交流互动中去。教师也可以安排学生以个人或小 组为单位进行中国文化展示, 这样才能调动学生学 习兴趣, 使学生更好地接受思政教育成为可能。

\section{4. 创新教学理念}

高等教育的核心是关注学生的心智发展, 大英语 教育不仅是教会学生英语语言知识, 更重要的是培养 学生的综合素养,为社会主义事业培养合格的接班人。 教师在英语课堂上应打破“一言堂”的传统授课模式, 不应该把学生视为课程知识的容器, 而应将之视为 课程的积极合作者。大学英语老师应不断探索教学方 法, 设计出符合当今青年学生认知方式的教学活动。 可以采用案例分析、小组讨论、辩论、汇报展示、情 景短剧、知识竞赛等形式, 用启发式、探究式、讨论 式、参与式、翻转课堂等教学方法, 调动每个学生的 参与热情, 使课堂活跃起来。让学生在学习语言知 识的同时了解社会, 提升学生的自主学习能力和团队 合作能力。

大学英语老师应该把线上和线下两种教学手段 
结合起来, 充分利用网络资源, 拓展学习资源。慕课, $\mathrm{U}$ 校园等网络学习平台为大学英语教学提供了丰富 的线上资源和网络互动平台, 可以更好地让学生成为 课程的积极合作者。教师可提前将大学生关心的时事 政治或相关的传统文化内容发布到网络学习平台上, 并提出问题让学生运用英语进行讨论, 之后在课堂上 进行展示。也可以根据教学内容让学生自己查找相关 热点问题或文化背景知识, 然后在网上分享。网络 是当代大学生获取咨询的重要渠道, 利用好这个渠道, 让学生参与对现实问题的讨论, 提出解决方案, 不仅 能够调动学生学习的积极性, 更能够让学生获得机 会去输出自己的思想、观点, 提高思想政治意识和觉 悟, 激发他们的社会责任感。达到思政教育的良好效 果。

\section{5. 创建团队合作}

大学英语课程思政的改革和建设, 需要各部门从 上到下协同合作，所有英语教师群策群力。实践证明， 许多优质课程、“金课”都是团体合作的成果。单枪匹 马很难设计出精良的课程, 只有团队协作才能整合资 源, 互通有无, 因此国家教育部鼓励课程改革和课程 建设中的团队协作。

英语教师可以以教研室为单位集体备课, 共同研 读教材, 讨论和挖掘思政素材, 设计教学活动。也可 以分成不同任务小组分工协作, 比如可以分成资料收 集小组, 教案撰写小组, 课件制作小组等, 这样可以 提高工作效率。小组成员之间也可以组织教学观摩, 进行同行互评、反思研讨, 开展教学讲座、课题小组 说课等活动。英语教师团队可以邀请思政理论课老师 加入, 英语老师可以走进思政课堂听课, 也可以邀请 思政老师帮忙设计思政教学内容, 以弥补英语教师思 政知识的不足。这些活动为教师创造学习和交流的环 境, 能够帮助大学英语教师更新教学知识, 改进教学 方法, 提升教学水平, 实现持续发展, 为大学英语课 程思政的顺利进行提供保障。

\section{6. 建立长效发展机制}

在课程思政背景下, 大学英语课程思政要做好顶 层设计, 通过统筹规划和管理, 构建可执行的长效职 业发展机制, 以促进英语教师的职业发展 [3]。学校 可定期邀请课程思政改革的专家到校作讲座, 或邀请 其他院校已取得课程改革效果的教师团队来校做经 验分享的交流, 以帮助教师了解课程思政的最新动态。 学校还应该为实施大学英语思政教学改革的教师提 供外出培训的机会, 让老师走出去, 去汲取先进理念, 学习有效方法, 然后将这些宝贵的经验带回来, 在本 校实施推广。对于进行大学英语思政教研的教师, 学 校要给予科研经费的支持, 鼓励其结合国家政策要求, 以课程思政为依托进行课程改革。对于教师的教学评 价, 学校应给予一定的政策指引。学校应当建立健全 课程思政建设成效考核评价体系, 将教师参与课程思
政建设情况和教师考核评价、岗位聘用、评优奖励等 方面建立联系。充分利用现代信息技术手段，促进优 质资源在各区域、层次、类型的高校间共享共用。通 过长效的发展机制的构建, 大学英语课程思政才能顺 利开展, 大学英语教师的职业发展前途才更光明, 从 而更好的为广大学生服务。

\section{5. 结论}

立德树人是每一位教育工作者的使命。在课程思 政的大背景下，高校英语老师更应该不忘初心，牢记 使命。加强育人意识, 提高思政素养, 深挖教材思政 元素, 提高对教材以外的思政素材的拓展能力。采取 灵活有效的教学方法, 以春风化雨, 润物无声的隐性 方式, 将课程思政融入日常教学中, 为国家培养品德 高尚，政治正确的社会主义接班人。

\section{REFERENCES}

[1] Xinhua (2016) President Xi calls for strengthened ideological work in colleges http://en.people.cn/n3/2016/1208/c90000-9152526. $\mathrm{html}$

[2] Xinhua (2020) The Ministry of Education issued a guiding outline to promote the ideological and political work in higher education institutions http://hlj.people.com.cn/n2/2020/0605/c338554-34 065944.html

[3] Wang, L.R. (2020) On the career development of College English teachers under the background of "ideological and political education in curriculum". J. Journal of Jilin Radio and TV University, Commun. 4: 27-28.

[4] Xi, H.Q. (1984) Research on the College English Teachers' Professional Development under the Background of "Ideological and Political Education in Curriculum". J. The Theory Practice of Innovation Entrepreneurship, Commun. 10(19): $69-71$. 